\title{
Sustainability of multi-skin facades
}

\author{
Yang Hui ${ }^{1, *}$ and Kirill Lushin ${ }^{2}$ \\ ${ }^{1}$ Beijing University of Civil Engineering and Architecture, Beijing Municipality Key Lab of Heating, \\ Gas Supply, Ventilating and Air Conditioning Engineering School of Environment and Energy \\ Engineering, China \\ ${ }^{2}$ Moscow State University of Civil Engineering, Yaroslavskoe shosse, 26, Moscow, 129337, Russia
}

\begin{abstract}
The paper considers the issues of buildings multi-skin envelope construction. Such a constructions is often used for buildings with wet inside air and for buildings with low energy consumption. A number of factors effect on the durability, sustainability and other properties of facade during the whole lifecycle of a building.
\end{abstract}

\section{Introduction}

For many years in XX century most of multi-layer facades in Europe and Asia were made for decreasing the influence of wet conditions of indoor air on performance of heat insulation of walls. This type of facades well known as double-skin facades with ventilated air gap. Or even hinged facade systems or ventilated facade. The traditional field for ventilated facades in Russia and China was industrial and public buildings with an extremely wet indoor air. The movement of external cold and dry air in between of the layers allows to maintain the material of the insulation layer in a non-wet condition [1]. The section of described construction is shown on Fig.1

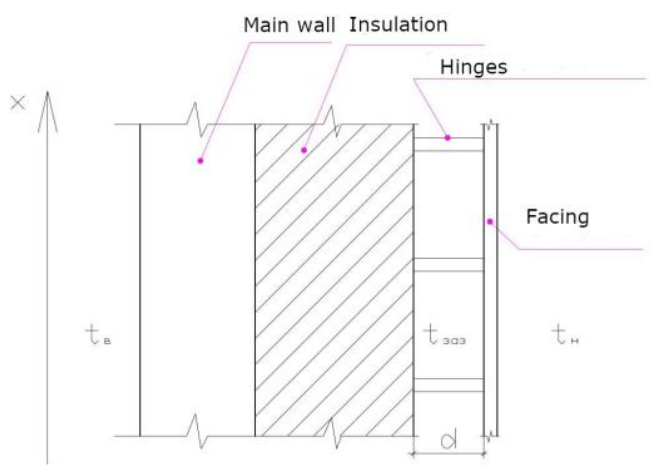

Fig. 1. The design of a multi-layer facade with a ventilated air gap, longitudinal vertical section $\left(t_{B}\right.$ and $\mathrm{t}_{\mathrm{H}}$ - respectively, tempera-ture differing from each other outside and inside the building, ${ }^{\circ} \mathrm{C}$; tзаз air temperature in the air gap, ${ }^{\circ} \mathrm{C}$; $\mathrm{d}$ - width of the air layer, as a rule expressed in $\mathrm{mm}$ ).

\footnotetext{
* Corresponding author: LushinKI@mgsu.ru
} 
The next important aspect of double-skin facades with ventilated air gap wide usage is the permanent will of architects and designers to combine the different functions of facades. Some examples of such approaches implementation are shown in Figures 2 and 3.

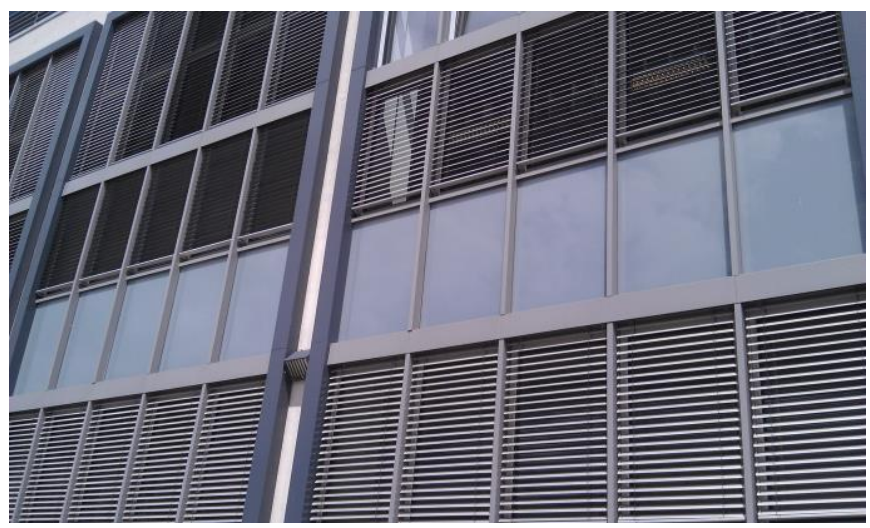

Fig. 2. An example of a simple sun shield on the outer surface of the wall in a temperate climate (Berlin, Germany. Photography from a personal archive of authors).

In our days on of the most often example of functions combining in a multi-layered enclosing structure is the attempts of architects to use the whole surface of the building in a useful way by placing photovoltaic elements of renewable energy systems - solar panels (PV) - on the shielding layer as shown on Fig.3. This extremely obvious technical decision is limited by a number of problems. If they will be totally ignored during the design period, they could give an unexpected effect during facades operation.

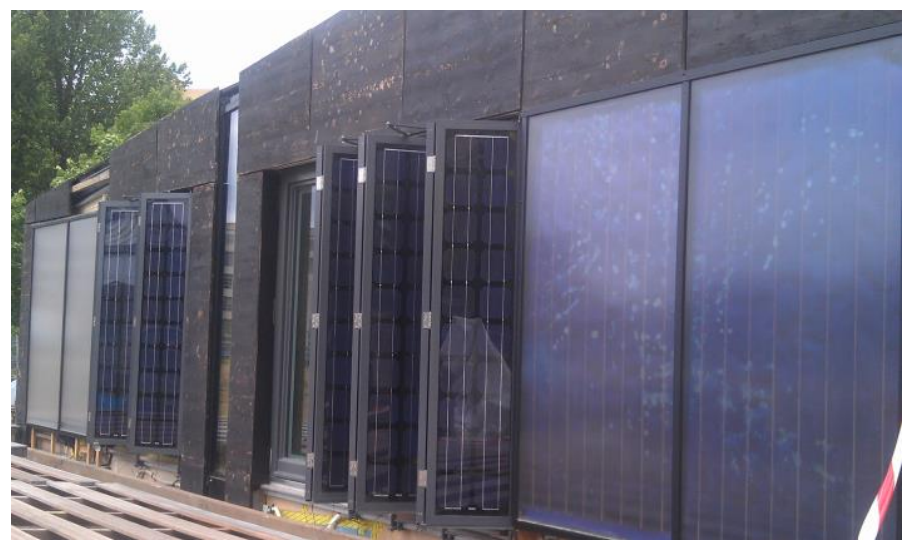

Fig. 3. An example of combining the functions of the protective screen and the photovoltaic element (PV) of the power supply system, implemented at the experimental facility of the energy-efficient building by stuff and students of the University of Applied Sciences (HTW, Berlin, Germany. Photography from the personal archive of the authors).

As shown in Fig. 3, even on a one store building, a protective screen with a combined function of PV element [2] is a product of decent size and area. 


\section{Review}

A deep and significant influence on the systematization of all data, knowledge's and classification of external walls and building envelope parts was provided by Yu. Granik [3]. The term screened facades was replaced with the abbreviation NFS (Rus), which means hinged facade systems. In situation their active use in construction, the frequency of their mention can create the wrong impression that shielded facades are the NSF as they are. However, as we have already shown, the variants of technical solutions can be different and most correct way is to give the generic name of multi-layer facades with a shielding outer layer. In this case, various special cases can be analysed from different angles of view among different authors. Thus, the other characteristic and extremely common name for this type of facade structures is the term "ventilated facades" [4].

Many authors, for example, Yuriy Tabunshchikov [5] and Vladimir. Kozlov [6], note that only facades can be called ventilated, for which the manufacturer of the elements provides in the very design of the screen openings, slots, holes, perforations or other solutions for air access in the upper and lower parts of the facade. Similarly, the design of the facade can provide for the use of entirely perforated panels on its shielding part. However, it should always be remembered that the sun shield does not need to be located parallel to the protected surface $[7,8,9]$. In architecture well known many ways of shading parts of facades for all kinds of fractures in the geometry of surfaces, columns and other often decorative elements.

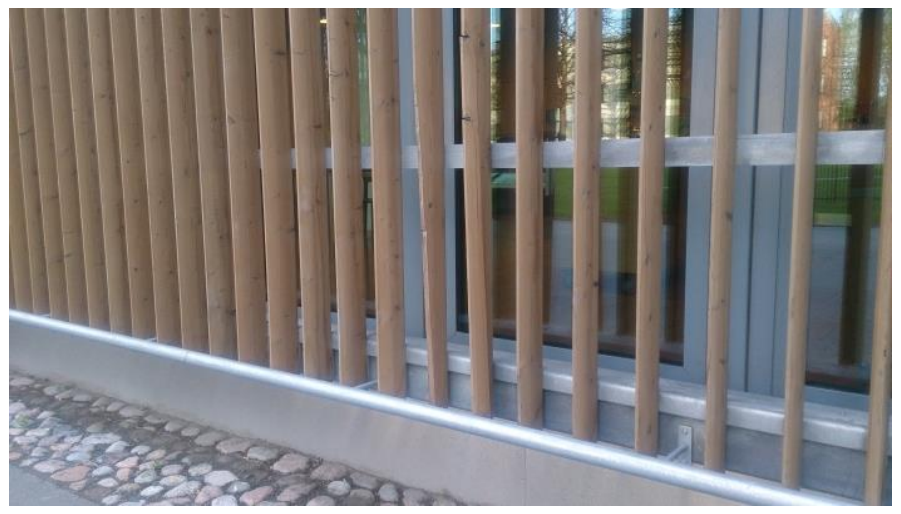

Fig.4. A typical design of a sun screen made of local materials with the arrangement of shielding elements perpendicular to the protected surface. A photo from a personal archive of authors.

Figure 4 shows the construction of a sun shield in one of the buildings in northern region [10] (Mikkeli, Finland), made of local materials with a shield placed perpendicular to the protected surface. Thus, following the definitions in [5] and [6], the construction depicted in Figure 5 will also be a ventilated façade. Most experts will disagree with that. Thus, when considering ventilated facades, it is necessary to clarify the definition by using definition detailed with words about existing upward flow of air in the gap between the screen and the supporting subbase.

The screen must be reliably fixed [11] on the supporting sub-base by means of a system of brackets, supports or suspensions, which must have considerable structural strength.

Since in a number of cases, their bearing capacity should be sufficient to retain not only the material of the facing, but also the insulation layer, as we have shown before. And in some cases the entire construction and all elements of the photovoltaic cell. Special and still not discussed requirements should be made when placing activated elements [12], i.e. movable screens on the sufficient hinged supports. Nevertheless, the approach proposed in 
[5] to the classification of ventilated facades can be considered as traditional for experts in Russia [13].

The variety of the multi-layered facade with a ventilated gap made in the form of longitudinal vertical canals is well studied and is presented in the work of N. Nizovtseva, V. Beliy and A. Sterligov [14]. Such a construction doesn't fully correspond to the definition of multi-layer shielded facades. The outer facing layer only partly works as a screen in that part of its area that covers the air channels. In addition, a contradiction arises with the definition proposed in [5] и [6]. However, the approach realized in work [14] is applicable also in task of analysing the parameters of the shielding part of multilayer facades.

An effective method for studying the air-thermal conditions of hinged facade systems was demonstrated in [15] by a group of scientists from Spain (Christina Sanjuan, Maria Nuria Sanchez, Ricardo Enriquez, Mariadel Rosario, Heras Celemin). The authors [15] succeeded in carrying out a laboratory experiment on the basis of measuring the velocity of a two-dimensional field of moving particles. As the indicator particles that were to be illuminated by the laser beam, pairs of olive oil evaporating from the open surface located at the bottom of the test bed and drawn into the air stream were used. In the work it was possible to demonstrate clearly that the greatest intensity of air movement in the air layer is achieved in the middle-height part of the facade.

In the work of N. Vatin and D. Nemova [16] was shown an approach to the analysis of the air-thermal conditions of the air gap in facade with a detailed analysis of the wind and gravity pressure distribution along the facade surface. Then in [16] was presented the results of calculating the dependence of the air velocity in the air gap, depending on its width. It is characteristic that, with an increase in the cross-section for air movement, its velocity can both increase and decrease. Clearly visible is the boundary when the effect achieved from reducing the resistance of the flow section, begins to be compensated for by the lack of air flow through the slots of the lining and the speed of its movement drops. Under the conditions of our task, this may mean limiting the possibilities for removing excess heat from the lining or sunscreen design. In [16], the authors propose to focus designers' attention on increasing the area and the number of openings through which air can enter the gap as a measure of improving simple hinged facade structures without movable screening elements. Such results in general do not contradict the data and conclusions obtained in other conditions by one of the authors of this publication [17].

\section{Materials and methods}

The presence of significant temperature changes on the facing surface of hinged facade systems was noted during the studies of the air-thermal conditions of air gaps, which was carried out in order to predict the state and perspectives of the thermal protection properties of the thermal insulation layer from mineral wool boards as part of a multilayer structure. During the research it was repeatedly noted that air temperature in the interlayer itself, which varies considerably in height, is of great importance for the air-thermal regime of the air layer of the hinged facade. A significant influence on both the temperature dynamics and its maximum value have the arrival of solar radiation [17], which is taken into account by means of the conditional temperature of the outside air $\left(t_{n}^{a p b}\right)$, determined by the formula $1[18]$.

$$
t_{n}^{a r b}=t_{n}+\frac{I_{c} \cdot \rho}{\alpha_{n}}
$$


here $\mathrm{t}_{n}$ is the value of the outside air temperature, ${ }^{\circ} \mathrm{C} ; \rho$ - coefficient of absorption of solar radiation, fraction of units;

$\alpha_{n}$ - - heat transfer coefficient of the external surface, $\mathrm{W} /\left(\mathrm{m}^{20} \mathrm{C}\right) ; I_{c}$ is the intensity of solar radiation (direct and scattered) on the vertical surface, $\mathrm{W} / \mathrm{m}^{2}$.

Then was made the assumption that the second component of equation 1 can exert a multiple effect on the resulting conditional temperature of the air layer $\left(t_{n}^{a p b}\right)$ in some periods. Air, in view of its low heat capacity [19], is an inefficient coolant [20] and in the case where the intensity of heat input [21] on the vertical surface of the screen is maximal, one does not have to count on effective heat removal from this surface by air moving behind it in the interlayer. To assess the degree of influence of air movement in the air layer and the dynamics of the temperature change of the shielding surface, it was decided to observe the characteristic design of the hinged facade with the registration of a number of parameters and, in particular, the air temperature in the air layer. A similar approach to a high-rise building [22] in its upper part with minimal shading should show more expressing result [23].

\section{Results and conclusion}

The research proposed the assumption of significant differences in the temperature of the air layer and the face of the shielding during the operation of the building. Taking into account main features of photovoltaic cells and more then all intensive self-heating and dark surface, one should pay attention to the fact that air movement in the air layer can not give the necessary effect on removal of heat from the surface and hinges of the shielding.

Negative effect of low heat capacity of air will be intensified by its high temperature. At summer time, for example. Similarly, it is necessary to pay special attention to the operation mode of various moving shielding elements, since the temperature deformations of large elements of such facades can cause a change in the mobility of hangers and hinged supports.

\section{References}

1. N. Karimi, E. Sediadi, L. Y. Wah, Energy saving in residential apartments by using $P V$ shading. Inter. J. Appl. Engin. Res., 36012-36015, 10, (2015)

2. Y. Li, C. Liu, Revenue assessment and visualisation of photovoltaic projects on building envelopes. J. Clean. Prod., 177-186, 182, (2018)

3. YU. D. Granik Primenenie fasadnykh sistem v zhilishhno-grazhdanskom stroitel'stve, Energosberezhenie, 84-88, 4, (2005)

4. I. A. Mekhnetsov Kriterii vybora uteplitelej dlya navesnykh ventiliruemykh fasadov // Prom. i grazhd. Str., 54-58, 7, (2006)

5. YU. A. Tabunshhikov. Teploustojchivost' pokrytij s ventiliruemoj proslojkoj. avtoref. diss. kand. tekhn. nauk, M., NIISF, (1968).

6. V. V. Kozlov Analiticheskij metod rascheta dvizheniya vozdukha v vozdushnom zazore ventiliruemogo fasada s oblitsovkoj, soderzhashhej periodicheskie razryvy. Stroitel'naya fizika v XXI veke - M. NIISF RAASN, 65-73, (2006)

7. Li Xue, Peng Jinqing, Li Nianping, Wang Meng, Wang Chunlei, Study on Optimum Tilt Angles of Photovoltaic Shading Systems in Different Climatic Regions of China // Procedia Engineering 205:1157-1164, (2017), [DOI: 10.1016/j.proeng.2017.10.185]

8. A. A. Volkov. Kibernetika stroitel'nykh sistem. Kiberfizicheskie stroitel'nye sistemy. Prom. i grazhd. Str., 4-7, 9, (2017) 
9. K. I. Lushin Edinaya tekhnologicheskaya sistema zdaniya i aktual'nye zadachi podgotovki stroitel'nykh kadrov. Vestnik MGSU, 5-6, 3, (2015)

10. O. Samarin, K. Lushin, S. Paulauskaite, K. Valančius. Influence of the outside climate parameters on the selection of the optimum combination of the energy saving measures. // Techn. and Econ. Devel. of Econ., 480-489,15 (3), (2009)

11. Rekomendatsii po proektirovaniyu navesnykh fasadnykh sistem s ventiliruemym vozdushnym zazorom dlya novogo stroitel'stva i rekonstruktsii zdanij. M., Moskomarkhitektura, 108 (2002)

12. Philipp Molter, Bonnet Cecile, Wagner Tobias, Michael Reifer, Tillmann Klein Autoreactive components in double skin facade. Conf.: Adv. Build. Skins, October, Bern, SwitzerlandAt: Bern, Switzerland Volume: 17, (2017)

13. M. Petrichenko, D. Nemova, E. Kotov, D. Tarasova, V. Sergeev Ventilated facade integrated with the HVAC system for cold climate. Magaz. of Civ. Engin., 47-58, 77 (1), (2018)

14. M. Nizovtsev, V. Belyi, A. Sterlygov. Energy and Build., 60-69, 75, (2014)

15. Christina Sanjuan, Maria Nuria Sánchez, Ricardo Enríquez, Maria del Rosario Heras Celemin,EnergyProcedia, 1216 - 1225, 30, 2012

16. M. Petrichenko, N. Vatin, D. Nemova Improvement Of The Double Skin Facades // Appl. Mech. and Mater., 41-48, 725-726, (2015)

17. V. G. Gagarin, V. V. Kozlov, K. I. Lushin. Skorost' dvizheniya vozdukha v proslojke navesnoj fasadnoj sistemy, pri estestvennoj ventilyatsii // Zhilishhnoe stroitel'stvo, 1417, 10, (2013)

18. V. M. Il'inskij. Stroitel'naya teplofizika. 320, (M., 1974)

19. Michael Donn, Geoff Thomas, Mohammad Al-Janabi Design Of Double Skin Facades For Fire Safety, (2018) [DOI: 10.1002/fam.2509]

20. D. V. Abramkina, Modelirovanie svobodno konvektivnykh techenij v sistemakh ventilyatsii s teplovym pobuzhdeniem. Vestnik dagestanskogo gosudarstvennogo tekhnicheskogo universiteta. Tekhnicheskie nauki. 136-145, 3, (2017)

21. O. D. Samarin, K. I. Lushin Energeticheskij balans zhilykh zdanij i ego ehksperimental'nye issledovaniya. Vestnik MGSU, 423, 2, (2009)

22. V. G. Gagarin, K. I. Lushin, V. V. Kozlov, A. Yu. Neklyudov, Conf. CCHVAC 2015, 103-111, (2016)

23. O. Samarin, K. Lushin, S. Paulauskaite Techn. and Econ. Devel. of Econ., 67-72, 13 (1), (2007) 